NISTIR 6854

\title{
Simulation of the Dynamics of a Fire in a Two-Story Duplex - Iowa, December 22, 1999
}

Daniel Madrzykowski

Glenn P. Forney

William D. Walton 
NISTIR 6854

\section{Simulation of the Dynamics of a Fire in a Two-Story Duplex - Iowa, December 22, 1999}

Daniel Madrzykowski Glenn P. Forney William D. Walton

Building and Fire Research Laboratory National Institute of Standards and Technology

Gaithersburg, MD 20899-8661

January 2002

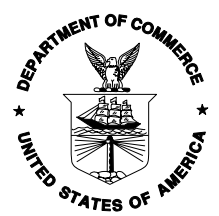

U.S. Department of Commerce Donald D. Evans, Secretary

Technology Administration Phillip J. Bond, Under Secretary for Technology

National Institute of Standards and Technology Arden L. Bement, Jr., Director 


\section{TABLE OF CONTENTS}

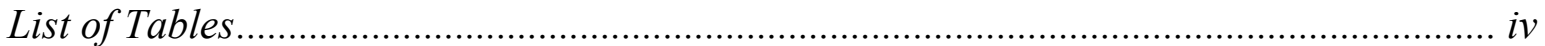

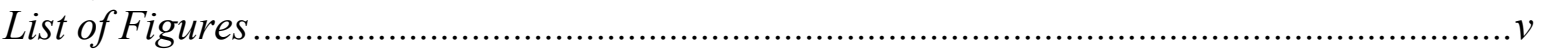

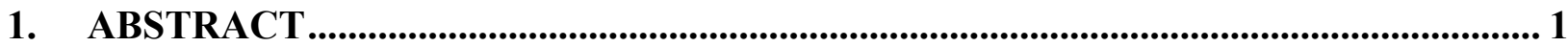

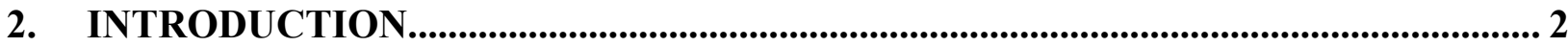

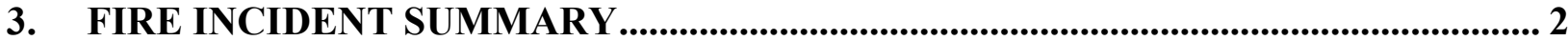

4. NIST FIRE DYNAMICS SIMULATOR (FDS) ........................................................ 3

4.1. MODEL UNCERTAINTY ...................................................................................... 3

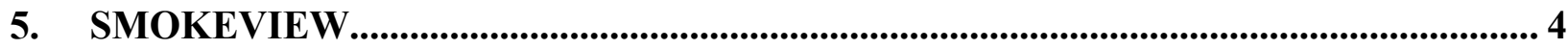

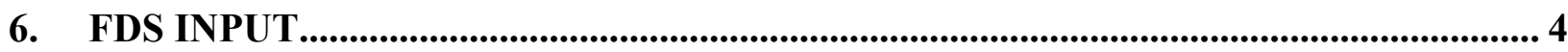

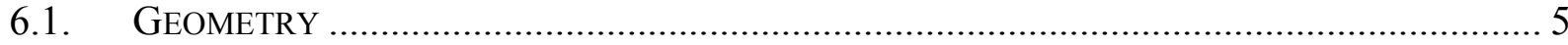

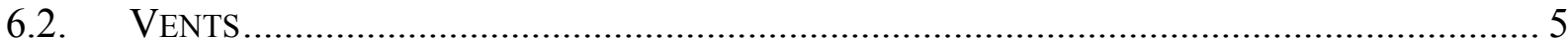

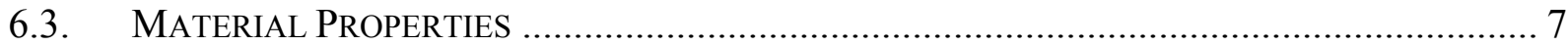

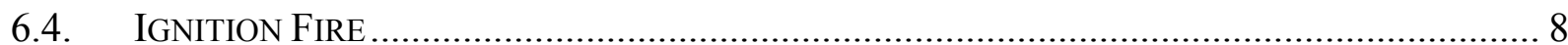

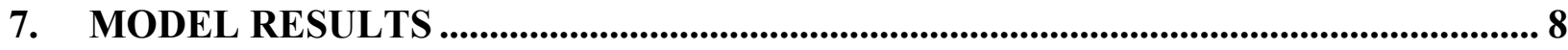

7.1. STRUCTURE AND CONTENTS SIMULATION ........................................................... 8

7.2. FIRE SIMULATION - TEMPERATURE PREDICTIONS..................................................... 9

7.2.1. Flame SHEET FIRE SIMULATION ......................................................................... 10

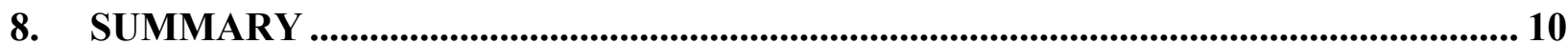

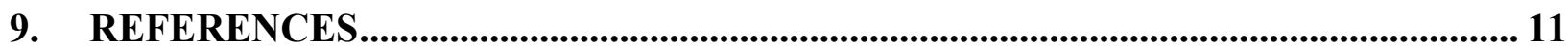

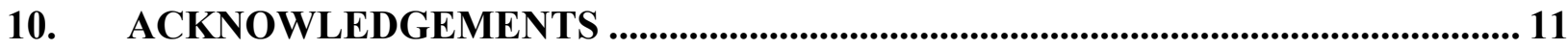




\section{LIST OF TABLES}

Table 1. Approximate Incident Timeline ............................................................................ 5

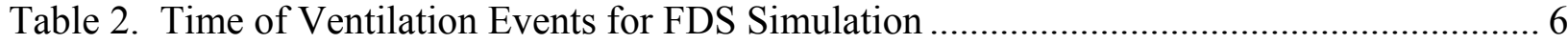

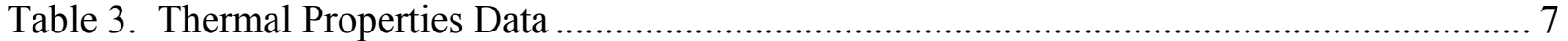

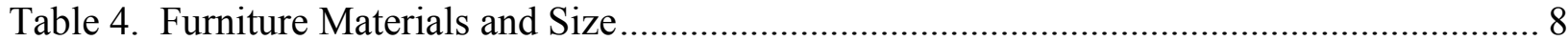




\section{LIST OF FIGURES}

Figure 1. Front of structure. Duplex on right was the unit of fire origin.............................. 12

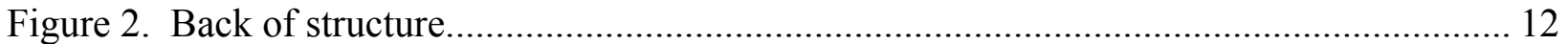

Figure 3. Plan view of $1^{\text {st }}$ Floor. Ceiling height of $1^{\text {st }}$ floor $2.8 \mathrm{~m}$, except for kitchen area, $2.4 \mathrm{~m}$.

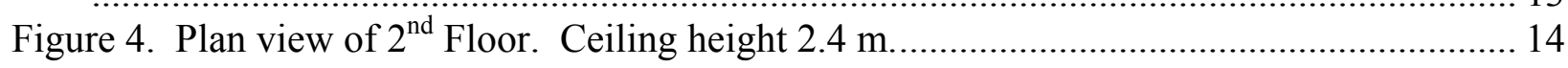

Figure 5. Results of fire extension from kitchen window up to rear bedroom........................ 15

Figure 6. Inside view of kitchen, area of origin............................................................. 15

Figure 7. Dining Room with table and chairs. .............................................................. 16

Figure 8. Living room with sofa from front hall doorway................................................... 16

Figure 9. $1^{\text {st }}$ floor hall with doorway to living room on left $\&$ front doorway on right.............. 17

Figure 10. Stairway and $1^{\text {st }}$ floor hall from front doorway................................................. 17

Figure 11. Second floor landing and stairwell looking toward front of structure....................... 18

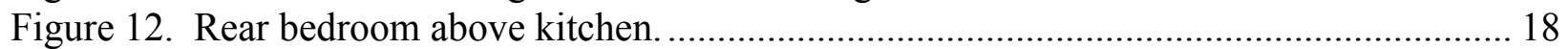

Figure 13. Right front of duplex. Front bedroom window shown with lower portion open. Front door shown closed. The outer box frame represents the boundary of volume modeled...... 19

Figure 14. Yard side of duplex. Outer wall removed to show living room and dining room on the first floor and front and middle bedrooms on the second floor. ................................ 19

Figure 15. Rear of duplex. The kitchen, with stove and cabinets, and a bathroom are shown on the $1^{\text {st }}$ floor, the rear bedroom, above the kitchen, and a bathroom are on the $2^{\text {nd }}$ floor...... 20

Figure 16. Shared side of duplex. The rear of the duplex is on the left of the figure. From the left, a bathroom, the kitchen, a closet under the stairs, the stairway and lower hall can be seen on the $1^{\text {st }}$ floor. Also from the left, a bathroom, upper hall and front bedroom can be

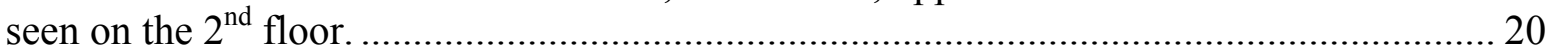

Figure 17. Example of 3 dimensional grid arrangement................................................ 21

Figure 18. Thermal conditions at approximately 8:32 AM (491 s into simulation).................. 21

Figure 19. Thermal conditions at approximately 8:33 AM (524 s into simulation).................. 22

Figure 20. Thermal conditions at approximately 8:34 AM (605 s into simulation).................. 22

Figure 21. Estimated flame boundary covering stove top at approximately 8:28 AM............. 23

Figure 22. Estimated flame boundary extending across kitchen ceiling and venting out of upper

portion of kitchen window at approximately 8:32 AM. .............................................. 23

Figure 23. Estimated flame boundary spreading through the dining room and into the living room at approximately 8:33 AM. Flames continue to spread up the outside of the kitchen.

Figure 24. Estimated flame boundary spreading through the dining room and into the living room at approximately 8:34 AM. 
Simulation of the Dynamics of a Fire in a Two-Story Duplex,

Iowa, December 22, 1999

\author{
Daniel Madrzykowski \\ Glenn P. Forney \\ William D. Walton
}

\title{
1. ABSTRACT
}

This report describes the results of calculations using the NIST Fire Dynamics Simulator (FDS) that were performed to provide insight on the thermal conditions that may have occurred during a fire in a two-story duplex house on December 22, 1999 in Iowa. Input to the computer model was developed from 3 sources; investigators from the Bureau of Alcohol Tobacco and Firearms (ATF), investigators with the National Institute for Occupational Safety and Health (NIOSH) and from material properties taken from the FDS database.

An FDS model scenario was developed that best represented the actual building geometry, material thermal properties, and fire behavior based on information and photographs from ATF. The results from this model scenario are provided with this report.

The FDS calculations that best represent the reported fire conditions indicate that a fire originating on the kitchen stove spread through the house resulting in flames that engulfed the stairwell to the second floor within approximately 9 minutes from the start of flaming ignition on the stove.

The critical event in this fire was the onset of flashover conditions in the kitchen. Within $60 \mathrm{~s}$ after the flashover occurred in the kitchen, the flames had spread through the dining room, living room and up the stairway.

Key Words: cfd models; computer graphics; fire dynamics; fire fatalities; fire fighters; fire investigations; fire models; flashover; ventilation 


\section{INTRODUCTION}

Part of the mission of the Building and Fire Research Laboratory (BFRL) at the National Institute of Standards and Technology (NIST) is to conduct basic and applied fire research, including fire investigations, for the purposes of understanding fundamental fire behavior and to reduce losses from fire.

On December 22, 1999 a fire in a two story duplex house in Iowa claimed the lives of three children and three firefighters. The fire occurred in the right half of a two story duplex as shown in Figure 1. In this figure, the entry doors to the two units are located next to each other, under the porch roof on the left side of the photograph. The backside of the house is shown in Figure 2. The heavily damaged area on the $1^{\text {st }}$ floor is the kitchen and the area above on the $2^{\text {nd }}$ floor is the rear bedroom. Plan views of the first and second floor are shown in figures 3 and 4 .

At the request and under the sponsorship of the National Institute for Occupational Safety and Health (NIOSH), NIST has examined the fire dynamics of this incident. NIST has performed computer simulations of the fire using the newly developed, NIST Fire Dynamics Simulator (FDS) and Smokeview, a visualization tool, to provide insight on the fire development and thermal conditions that may have existed in the residence during the fire. This report describes the input and the results of the NIST FDS Version 1.0 calculations.

\section{FIRE INCIDENT SUMMARY}

This account of the events relevant to this fire is based on information provided to NIST by the Bureau of Alcohol, Tobacco and Firearms (ATF) and NIOSH.

On the morning of December 22, 1999, a fire started in plastic materials on top of the stove in the kitchen on the first floor of the residence. An adult occupant, sleeping upstairs in the front bedroom, awoke to the cries of a child. The adult opened the front bedroom door to the hall and found hot smoky conditions. The adult returned to the front bedroom, opened a window on the front side of the house and called for help, alerting several neighbors. It is believed that the calls to 911 began shortly after this. The first call was received by the dispatcher's office at approximately 8:24 AM. The adult returned to the smoky upstairs hallway, found the crying child and exited the residence by the front bedroom window onto the roof of the front porch. Approximately two minutes later, 8:26 AM, firefighters and police began to arrive at the fire scene. The smoke plume was visible as firefighters approached the scene and there was little if any wind disturbing the plume. The adult occupant was outside with the child and explained that there were three children still in the house. The front door to the residence was forced open by a police officer at approximately 8:27 AM. The officer discovered heavy smoke conditions. He could not make entry into the house. At 8:28 AM, the first arriving crew of firefighters prepared to enter the residence and placed a call requesting additional firefighters. At approximately 8:31 AM, the Fire Chief arrived at the fire scene with an additional firefighter. Three fire fighters entered the house and brought two infants from upstairs bedrooms to the front 
door. Two police vehicles were used to transport the infants to the hospital. The fire chief was administering CPR to the second infant and was transported to the hospital. Based on radio transmissions, the first infant was enroute to the hospital at approximately 8:34 AM and the second infant was enroute to the hospital at approximately 8:35 AM. According to witness statements, the full fire involvement of the living room, leading to a fully involved fire condition in the stairwell, occurred as the infants were being transported to the hospital. A hose line had been advanced into entry foyer of the house. The "dry" hose line was placed on the floor, while the firefighter returned to the engine to charge the line. When the hose line was "charged" (pressurized with water) it was discovered that the hose had burned through and flames were coming out of the doorway to the house.

At approximately 8:48 AM, as a second fire crew made entry into the house and began to attack the fire with a hose line, a firefighter was discovered on the floor of the living room. Later the other two firefighters from the first crew were found on the second floor. One on the landing at the top of the stairs with a child victim and another in the doorway of the front bedroom. All three firefighters and the one child found in the house, and the two children taken to the hospital died from injuries caused by the fire.

The post fire investigation confirmed that the fire started in plastic material on the stove. The kitchen had fire damage throughout, consistent with a well-mixed, post-flashover fire environment, Figures 5 and 6 . In addition to the kitchen area, there was significant fire damage in the living room (Figure 8), the stairwell, second floor hallway (Figures 9-11) and the rear bedroom above kitchen (Figure 12). The dining room (Figure 7), the other bedrooms and the bathrooms had less fire damage than the other portions of the house. A timeline of the fire events is given in Table 1.

\section{NIST FIRE DYNAMICS SIMULATOR (FDS)}

NIST has developed a computational fluid dynamics (CFD) fire model using large eddy simulation (LES) techniques [1]. This model, called the NIST Fire Dynamics Simulator (FDS), Version 1., has been demonstrated to predict the thermal conditions resulting from a compartment fire [2,3]. A CFD model requires that the room or building of interest be divided into small three-dimensional rectangular control volumes or computational cells. The CFD model computes the density, velocity, temperature, pressure and species concentration of the gas in each cell. Based on the laws of conservation of mass, momentum, species and energy the model tracks the generation and movement of fire gases. FDS utilizes material properties of the furnishings, walls, floors, and ceilings to compute fire growth and spread. A complete description of the FDS model is given in reference [1].

\subsection{Model Uncertainty}

FDS can provide valuable insight into how a fire may have developed. However the model is only a simulation. The model output is dependent on a variety of input values such as material properties, times lines, geometry, and ventilation openings. Since perfect knowledge of every detail of the fire site, fuel load or fire timeline is never known, 
estimations are incorporated into the model. For example, the estimation of the energy release rate of an initial "source fire" as a starting point for fire development and spread throughout the structure is a necessary part of re-creating this fire scenario. Another estimation used in this case, the plaster ceilings and walls of the structure were modeled with the thermal properties of gypsum board. These estimations and others used in this simulation are further described in Section 6 of this report.

The ability of the FDS model to accurately predict the temperature and velocity of fire gases has been previously evaluated by conducting experiments, both lab-scale and fullscale, and measuring quantities of interest. For relatively simple fire driven flows, such as buoyant plumes and flows through doorways, FDS predictions are within the experimental uncertainty of the values measured in the experiments [2]. For example, if a gas flow velocity is measured at $0.5 \mathrm{~m} / \mathrm{s}$ with an experimental uncertainty of $\pm 0.05 \mathrm{~m} / \mathrm{s}$, the FDS model gas flow velocity predictions were also in the range between $0.45 \mathrm{~m} / \mathrm{s}$ and $0.55 \mathrm{~m} / \mathrm{s}$.

In large scale fire tests reported in [3], FDS temperature predictions were found to be within $15 \%$ of the measured temperatures and the FDS heat release rates were predicted to within $20 \%$ of the measured values. Therefore the results are presented as ranges to address these uncertainties.

\section{SMOKEVIEW}

Smokeview is a scientific visualization program that was developed to display the results of a FDS model computation. Smokeview produces animations or snapshots of FDS results [4].

A new feature of Smokeview allows the viewing of FDS output in 3-dimensional animations. An iso-surface is a three dimensional version of a contour elevation often found on topographic maps. In this report, a beta version of Smokeview was used in conjunction with FDS Version 1.0 to generate animated iso-surfaces to visualize the movement and spread of the fire.

\section{FDS INPUT}

Inputs required by FDS include the geometry of the structure, the computational cell size, the location of the ignition source, the energy release of the ignition source, thermal properties of walls, ceiling, floors and furnishings, and the size, location, and timing of door and window openings to the outside which critically influence fire growth and spread. The timing of the door and window openings used in the simulation given in Table 2 are based on an approximate timeline of the fire events in Table 1. 
Table 1. Approximate Incident Timeline

\begin{tabular}{clc}
$\begin{array}{c}\text { Incident } \\
\text { Time }\end{array}$ & \multicolumn{1}{c}{ Events } & $\begin{array}{c}\text { Simulation } \\
\text { Time } \\
(\mathbf{s})\end{array}$ \\
\hline $08: 24$ & First call reporting fire. & 0 \\
$08: 26$ & Fire fighters arriving on scene & 120 \\
$08: 27$ & Front door open & 180 \\
$08: 28$ & Fire fighters on scene requesting back-up & 240 \\
$08: 31$ & Fire Chief arrives on scene & 420 \\
$08: 33$ & Second infant removed from house by this time & 540 \\
$08: 34$ & First infant enroute to hospital. & 600 \\
$08: 35$ & Second infant enroute to hospital, hoseline burned & 660 \\
$08: 48$ & Discovered fire fighter on $1^{\text {st }}$ floor &
\end{tabular}

\subsection{Geometry}

The floor plans of the first and second floor of the duplex are shown in Figures 2 and 3. The two levels of the duplex are enclosed within a $13.4 \mathrm{~m}(44.0 \mathrm{ft}) \times 6.0 \mathrm{~m}(19.7 \mathrm{ft}) \mathrm{x}$ $5.4 \mathrm{~m}(17.7 \mathrm{ft})$ tall rectangular volume. For the FDS simulation this volume was divided into 64,800 computational cells. Each cell has dimensions of a $0.2 \mathrm{~m}(8 \mathrm{in}) \times 0.2 \mathrm{~m}(8 \mathrm{in}) \mathrm{x}$ $0.2 \mathrm{~m}$ ( $8 \mathrm{in})$ cube. The size of the interior walls, doorways, and windows were based on the dimensions of the house. The size and location of the walls, doorways, and windows are adjusted by FDS to correspond to the nearest computational cell location. This results in walls, used in the model, that appear thicker then they are in the actual house and stairs that are not uniform throughout.

\subsection{Vents}

This simulation considered three vents or openings from the structure to the outside, the front window in the front bedroom, the front door and the kitchen window. The lower portion of the front window in the front bedroom had an opening approximately $0.8 \mathrm{~m}$ $(2.6 \mathrm{ft})$ wide $\times 0.4 \mathrm{~m}(1.3 \mathrm{ft})$ high with a $0.4 \mathrm{~m}(1.3 \mathrm{ft})$ sill height. This vent was open during the entire simulation. The front doorway was $0.9 \mathrm{~m}(3.0 \mathrm{ft})$ wide $\mathrm{x} 2.2 \mathrm{~m}(7.2 \mathrm{ft})$ high. The front door opens at $180 \mathrm{~s}$ of simulation time. The kitchen window was $0.84 \mathrm{~m}$ $(2.76 \mathrm{ft})$ wide and $1.4 \mathrm{~m}(4.6 \mathrm{ft})$ high with a $0.8 \mathrm{~m}(2.6 \mathrm{ft})$ sill height. The windows in the 
house were composed of small panes with wood framing in between each pane. With a window of this design, it typically would not fail or break-out all at once due to a fire. To account for partial breakage of the window and smoke leakage from the kitchen to the outside or other parts of the structure, the window vent opened in three sections. The upper most $0.2 \mathrm{~m}$ (8 in) section of the kitchen window opened at $90 \mathrm{~s}$ into the simulation. This opening is intended to account for smoke leakage out of the kitchen. The top half of the kitchen window opened at $270 \mathrm{~s}$. This time was based on the gas temperatures being in excess of $400^{\circ} \mathrm{C}\left(750^{\circ} \mathrm{F}\right)$ near the upper portion of the window. The vent representing the kitchen window was completely opened at $510 \mathrm{~s}$ into the simulation. Again the window was opened based on the assumption that at $400{ }^{\circ} \mathrm{C}\left(750{ }^{\circ} \mathrm{F}\right)$ the wooden frame would be burning and creating excessive thermal stresses on the window glass [5].

Interior doorways were open with the exception of the following doors which were closed in the fire incident and therefore were also closed in the simulation: the door leading from the kitchen to the bathroom, the door to the closet in the dining room, the door between the dining room and the first floor hallway (see figure 3). On the second floor the door from the hallway to the bathroom was closed (see figure 4).

At the time of the fire there was no wind, therefore for the simulation it was assumed that openings to the exterior were at ambient pressure.

Table 2. Time of Ventilation Events for FDS Simulation

\begin{tabular}{|c|c|c|c|c|c|}
\multicolumn{1}{|c|}{} & \multicolumn{5}{c}{ Time of Event } \\
\hline Vent & $\begin{array}{c}\text { Initial } \\
\text { Conditions }\end{array}$ & $90 \mathrm{~s}$ & $180 \mathrm{~s}$ & $270 \mathrm{~s}$ & $510 \mathrm{~s}$ \\
\hline $\begin{array}{c}\text { Front Bed Room } \\
\text { Window }\end{array}$ & Open & Open & Open & Open & Open \\
\hline $\begin{array}{c}\text { Front Door } \\
\text { Kitchen Window, } \\
\text { Top 0.2 m (7.9 in) }\end{array}$ & Closed & Closed & Open & Open & Open \\
\hline $\begin{array}{c}\text { Kitchen Window, } \\
\text { Top Half }\end{array}$ & Closed & Closed & Closed & Open & Open \\
\hline $\begin{array}{c}\text { Kitchen Window, } \\
\text { Bottom Half }\end{array}$ & Closed & Closed & Open & Open \\
\hline
\end{tabular}




\subsection{Material Properties}

The ceiling material was composed of combustible wood fiber ceiling tiles, with the exception of the dining room, which still had the original plaster on lathe ceiling. The ceiling tiles were attached to wood furring strips, which were attached to the bottom of an existing plaster on lathe ceiling. The plaster ceiling assembly was modeled with the thermal properties of gypsum board.

The interior walls of the first and second floor hallways, the stairwell, bedrooms 2 and 3 and the wall between bedroom 1 and bedroom 2 were covered with wood paneling and modeled as thin pine. All other walls were covered with gypsum board.

The upstairs floor was modeled as pine. The downstairs floor was assumed to not contribute to the fire.

Several large furniture items were included in the scenario; kitchen cabinets, kitchen table, dining room table, living room sofa and two upholstered chairs. The model inputs utilized for each material type are given below in Table 3 and the size of the furnishings are given in Table $4[1,4]$.

Table 3. Thermal Properties Data

\begin{tabular}{|l|c|c|c|c|c|}
\hline Material & Thickness & $\begin{array}{c}\text { Ignition } \\
\text { Temperature } \\
(\mathrm{m})\end{array}$ & $\begin{array}{c}\text { Heat } \\
\text { Release } \\
\text { Rate } \\
\left({ }^{\circ} \mathrm{C}\right)\end{array}$ & $\begin{array}{c}\text { Thermal } \\
\text { Conductivity }\end{array}$ & $\begin{array}{c}\text { Thermal } \\
\text { Diffusivity } \\
(\mathrm{WW} / \mathrm{m} \mathrm{K})\end{array}$ \\
\hline Ceiling Tile & 0.025 & 330 & 300 & 0.14 & $8.3 \mathrm{E}-8$ \\
\hline $\begin{array}{l}\text { Gypsum } \\
\text { Board }\end{array}$ & 0.013 & 400 & 100 & 0.48 & $4.1 \mathrm{E}-7$ \\
\hline Pine & 0.013 & 390 & 200 & 0.14 & $8.3 \mathrm{E}-8$ \\
\hline Thin Pine & 0.008 & 390 & 200 & 0.14 & $8.3 \mathrm{E}-8$ \\
\hline $\begin{array}{l}\text { Upholstered } \\
\text { Cushion }\end{array}$ & 0.10 & 370 & 700 & 0.20 & $1.2 \mathrm{E}-6$ \\
\hline
\end{tabular}

In addition to wood dining furniture, a cut evergreen tree was located in the Dining Room. The tree's contribution to the fire was estimated by adding the heat release rate from a 2.5 $\mathrm{m}$ tall, $1.2 \mathrm{~m}$ wide Scotch Pine with a mass of $9.5 \mathrm{~kg}$ [6]. The peak heat release rate was approximately 1.6 MW. This was the smallest tree used in the referenced study and it appeared to be the best representation of the tree that was in the house. As a point of reference, the maximum peak heat release rate from a burning cut pine tree measured in the referenced study was 5.2 MW. 
In the model, the tree is represented by a rectangular box, $1.26 \mathrm{~m}$ by $0.8 \mathrm{~m}$ and $0.2 \mathrm{~m}$ above the floor. The box is the source of the energy emitted by the tree, much like a gas burner. In one of the simulations, the tree was assumed to have ignited based on the thermal conditions in the dining room at $400 \mathrm{~s}$. This did not significantly change the fire conditions in the structure and therefore the additional heat release rate input was eliminated from the final model simulation presented here.

Table 4. Furniture Materials and Size

\begin{tabular}{|l|l|l|}
\hline \multicolumn{1}{|c|}{ Item } & \multicolumn{1}{c|}{ Material } & \multicolumn{1}{c|}{ Size } \\
\hline $\begin{array}{l}\text { Kitchen Cabinets, } \\
\text { upper }\end{array}$ & Pine & $1.68 \mathrm{~m}$ wide, $0.4 \mathrm{~m}$ deep, $0.6 \mathrm{~m}$ high \\
\hline $\begin{array}{l}\text { Kitchen Cabinets, } \\
\text { lower }\end{array}$ & Pine & $1.68 \mathrm{~m}$ wide, $0.6 \mathrm{~m}$ deep, $0.9 \mathrm{~m}$ high \\
\hline Kitchen Table & Pine & $\begin{array}{l}1.0 \mathrm{~m} \text { wide, } 1.05 \mathrm{~m} \text { deep, } 0.2 \mathrm{~m} \text { thick, } \\
1.0 \mathrm{~m} \text { high }\end{array}$ \\
\hline $\begin{array}{l}\text { Dining Room } \\
\text { Table }\end{array}$ & Pine & $\begin{array}{l}1.26 \mathrm{~m} \text { wide, } 1.2 \mathrm{~m} \text { deep, } 0.2 \mathrm{~m} \text { thick, } \\
0.8 \mathrm{~m} \text { high }\end{array}$ \\
\hline Sofa & Upholstered cushion & $1.6 \mathrm{~m}$ wide, $0.63 \mathrm{~m}$ deep, $0.8 \mathrm{~m}$ high \\
\hline Chairs $(2)$ & Upholstered cushion & $0.84 \mathrm{~m}$ wide, $0.80 \mathrm{~m}$ deep, $1.20 \mathrm{~m}$ high \\
\hline
\end{tabular}

\subsection{Ignition Fire}

The fire started in plastic material on top of the stove. This fire source was approximated as a rectangular object representing the stove with a specified heat release rate coming out of a opening on the top. The "stove" can be seen in figure 15. The opening, which represents the fire area on top of the stove, is $0.4 \mathrm{~m}$ wide by $0.84 \mathrm{~m}$ deep and $1.0 \mathrm{~m}$ above the floor. The heat release rate of the fire was assumed to grow slowly, reaching a peak of approximately $400 \mathrm{~kW}$ in $270 \mathrm{~s}$. The actual fire may have taken longer to develop; the actual ignition time of the fire is unknown. The simulation was started with a flaming ignition that corresponded to the approximate time at which the adult occupant and the neighbors became aware of the fire.

\section{MODEL RESULTS}

\subsection{Structure and Contents Simulation}

Figure 13 shows a front perspective view of the right side unit of the duplex from the Smokeview model. The outer box frame lines represent the volume modeled. The solid base is used to indicate the inert first floor material. The closed front door, the partially 
open front bedroom window and the porch roof can be seen on the front side of the house. Figure 14 provides a side view of the model. The figure shows the front of the duplex on the left, moving to the right is the living room and then the dining room on the first floor. The front bedroom and middle bedroom can be seen on the second floor. The kitchen and rear bedroom are obstructed by the outside wall of the duplex on the far right. Significant pieces of furniture have been modeled on the first floor. Representations of a sofa and two chairs can be seen in the living room on the left side of the figure. The "floating square" in the dining room represents the dining room table and chairs. The kitchen window can be seen on the far right side of the house. Figure 15 provides a view of the simulated structure from the back. From this view the stove can be seen centered in the kitchen with the kitchen cabinets on the right side of the kitchen. The side of the house with the stairway is shown in figure 16. From the bottom left and moving toward the right on the first floor is a bathroom, the kitchen, a closet under the stairs and the entry foyer. On the second floor, another bathroom, the hall and open stairway and the front bedroom can be seen. The area on the far right represents an area outside the front of the house. The grid depicting the computational cell size is shown in figure 17. Each cell has dimensions $0.2 \mathrm{~m}(8 \mathrm{in}) \times 0.2 \mathrm{~m}$ (8 in) $\times 0.2 \mathrm{~m}(8 \mathrm{in})$.

\section{2. $\quad$ Fire Simulation - Temperature Predictions}

The simulation results in Figures 18 through 20 have had the outer walls removed to provide a clear view. The results are shown as a "slice" or a "plane" with a color bar that represents the corresponding numerical quantities. These figures provide "snapshots" of the calculated fire environment conditions that the firefighters may have been exposed to between 8:32 AM and 8:34 AM.

Figures 18 and 19 show the plane of temperatures that align with the center of the kitchen and dining room doorways. This plane is located $2.9 \mathrm{~m}(9.5 \mathrm{ft})$ into the duplex from the outside wall of structure. The second temperature plane shown in the figures is located along the centerline of the kitchen window.

In Figure 18, a distinct two-layer environment can be seen in the living and the dining room at $485 \mathrm{~s}$ into the simulation or approximately 8:32 $\mathrm{AM}$. In the living room the upper or hot gas layer temperatures are approximately $200{ }^{\circ} \mathrm{C}$ to $300{ }^{\circ} \mathrm{C}\left(390{ }^{\circ} \mathrm{F}\right.$ to $\left.570{ }^{\circ} \mathrm{F}\right)$. In the dining room the hot gas temperatures are approximately $300{ }^{\circ} \mathrm{C}$ to $450{ }^{\circ} \mathrm{C}\left(570{ }^{\circ} \mathrm{F}\right.$ to $840^{\circ} \mathrm{F}$ ). In both rooms, temperatures near the floor are near ambient. Gas temperatures in excess of $600{ }^{\circ} \mathrm{C}\left(1110^{\circ} \mathrm{F}\right)$ can be seen near the top of the kitchen doorway and at the top of the kitchen window.

Figure 19 shows the same thermal planes, $55 \mathrm{~s}$ later at $540 \mathrm{~s}$ of the simulation. By this time, gases in excess of $600^{\circ} \mathrm{C}\left(1110^{\circ} \mathrm{F}\right)$ had spread across both the dining room and the living room, potentially igniting the combustible surfaces in the top portion of these rooms. Other gases, hotter than the ignition temperature of wood, are shown leaving the kitchen window and spreading up the outside of the house. This rapid change is consistent with a flashover occurring in the kitchen. 
Figure 20 displays the plane of temperatures aligned with the center of the stairs, $0.4 \mathrm{~m}$ $(1.3 \mathrm{ft})$ into the house from the shared interior wall. Approximately $600 \mathrm{~s}$ or $10 \mathrm{~min}$ into the simulation, gases in excess of $600{ }^{\circ} \mathrm{C}\left(1110^{\circ} \mathrm{F}\right)$ have filled the open stairwell.

\subsubsection{Flame Sheet Fire Simulation}

Figures 21 through 24 show a series of views of the simulation that approximate the flame spread through the structure. The iso-surface simulation provides a three dimensional approximation of the flame surface area where fuel, heat and oxygen are present such that flames may exist. The flames can be seen covering the top of the stove at approximately $220 \mathrm{~s}$ or 8:28 AM, in figure 21. Approximately 4 minutes later, at 8:32 AM the fire has spread across the kitchen ceiling and has vented through the kitchen window as shown in figure 22. Figure 23 presents a side view of the house at approximately 8:33 AM. The flame front has extended through the dining room and into the living room. The final figure in the series, figure 24 , shows the estimated flame sheet spreading up the stairway at $600 \mathrm{~s}$ of simulation time or 8:34 AM. This series of figures is another demonstration of how rapidly the fire grew and quickly the flames spread through the house, trapping the firefighters.

\section{SUMMARY}

The NIST FDS computer simulation predicted fire conditions and events that correlate well with information from NIOSH and ATF. The model simulation was based on a fire that started on the kitchen stove. Smoke and hot gases from the fire began to spread through the house within seconds after ignition occurred. However, the FDS/Smokeview simulation of the flame front indicates that the fire itself did not spread beyond the kitchen until approximately 8 minutes after flaming ignition.

The critical event in this fire was the on-set of conditions consistent with flashover in the kitchen. At this point, approximately 8:32 AM, this fire started a transition from a single room and contents fire with smoke throughout the structure, to a fire that involved the majority of the structure within approximately $60 \mathrm{~s}$. The hot gas layer temperatures in the living room increased from approximately $200{ }^{\circ} \mathrm{C}$ to $300{ }^{\circ} \mathrm{C}\left(390{ }^{\circ} \mathrm{F}\right.$ to $\left.570{ }^{\circ} \mathrm{F}\right)$ to more than $600^{\circ} \mathrm{C}\left(1110^{\circ} \mathrm{F}\right)$ in less than a minute. The hot gases and flames continued to spread rapidly from the living room through the stairway to the second floor. This quick change in thermal conditions and flame spread through the duplex led to the 3 firefighters being trapped inside and succumbing to the effects of the fire environment. 


\section{REFERENCES}

1. McGrattan, Kevin B., Baum, Howard R., Rehm, Ronald G., Hamins, Anthony, Forney, Glenn P., Fire Dynamics Simulator - Technical Reference Guide, National Institute of Standards and Technology, Gaithersburg, MD., NISTIR 6467, January 2000.

2. McGrattan, Kevin B., Hamins, Anthony, and Stroup, David, Sprinkler, Smoke \& Heat Vent, Draft Curtain Interaction - Large Scale Experiments and Model Development, National Institute of Standards and Technology, Gaithersburg, MD., NISTIR 6196-1, September 1998.

3. McGrattan, Kevin B., Baum, Howard R., Rehm, Ronald G., Large Eddy Simulations of Smoke Movement, Fire Safety Journal, vol 30 (1998), p 161-178.

4. McGrattan, Kevin B., Forney, Glenn P., Fire Dynamics Simulator - User's Manual, National Institute of Standards and Technology, Gaithersburg, MD., NISTIR 6469, January 2000.

5. Cholin, John, M., Wood and Wood-based Products, NFPA Fire Protection Handbook, $18^{\text {th }}$ ed Section 4, Chapter 3, National Fire Protection Association, Quincy MA, 1997.

6. Stroup, D.W., DeLauter, L., Lee, J., and Roadarmel, G., Scotch Pine Christmas Tree Fire Tests, National Institute of Standards and Technology, Gaithersburg, MD., Report of Test FR 4010, December 1999.

\section{ACKNOWLEDGEMENTS}

The authors would like to thank Ms. Dawn Castillo, Mr. Richard Braddee and Mr. Thomas Mezzanotte of the NIOSH Fire Fighter Fatality Investigation and Prevention Program for their support of this research. The authors extend their appreciation to Special Agent Christopher Van Vleet and Andrew Cox of the Bureau of Alcohol, Tobacco and Firearms for their thorough documentation of the structure involved in this fire incident. Finally we would like to thank Dr. Kevin McGrattan for his continued development of the NIST Fire Dynamics Simulator Model. 


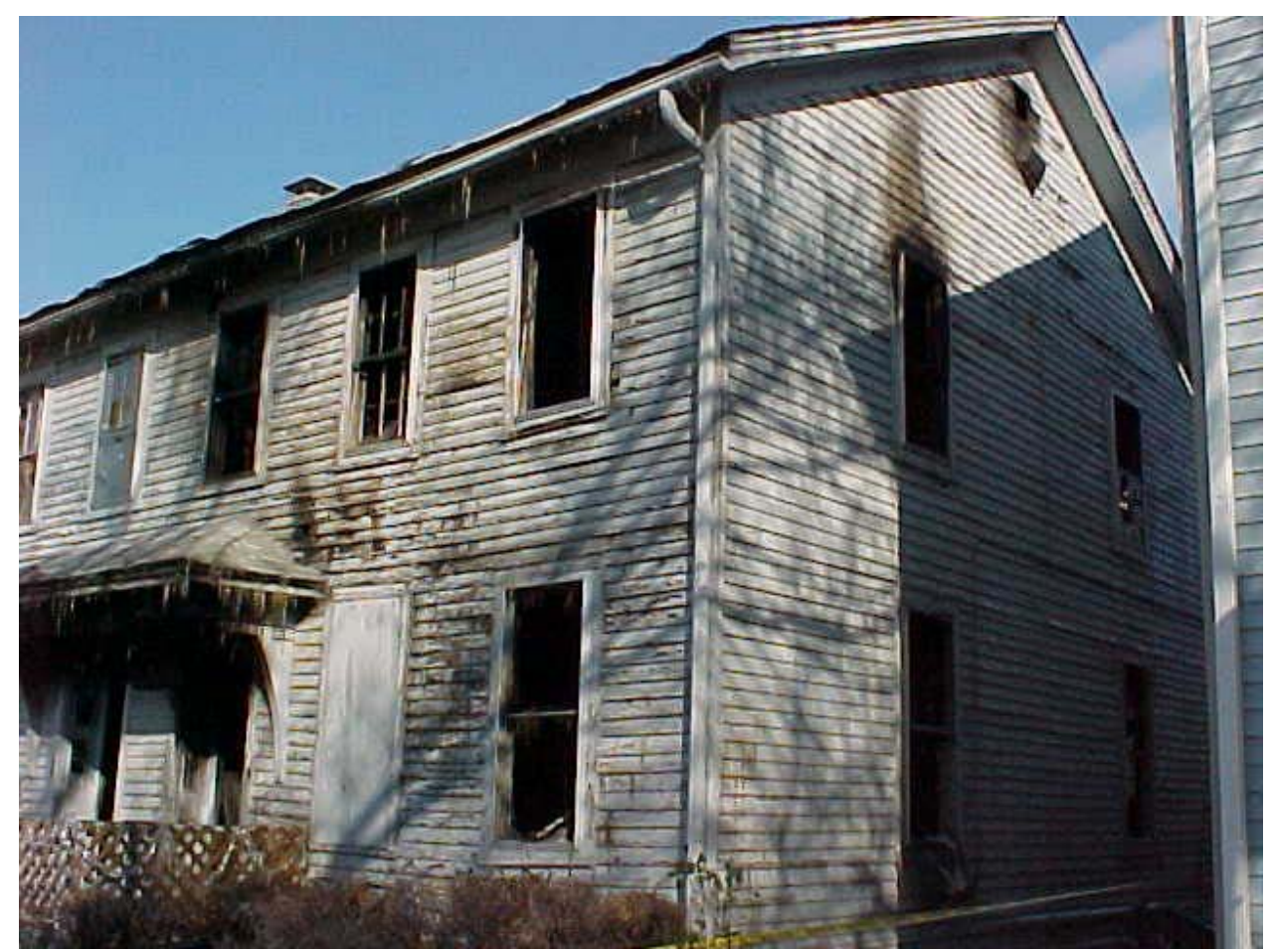

Figure 1. Front of structure. Duplex on right was the unit of fire origin.

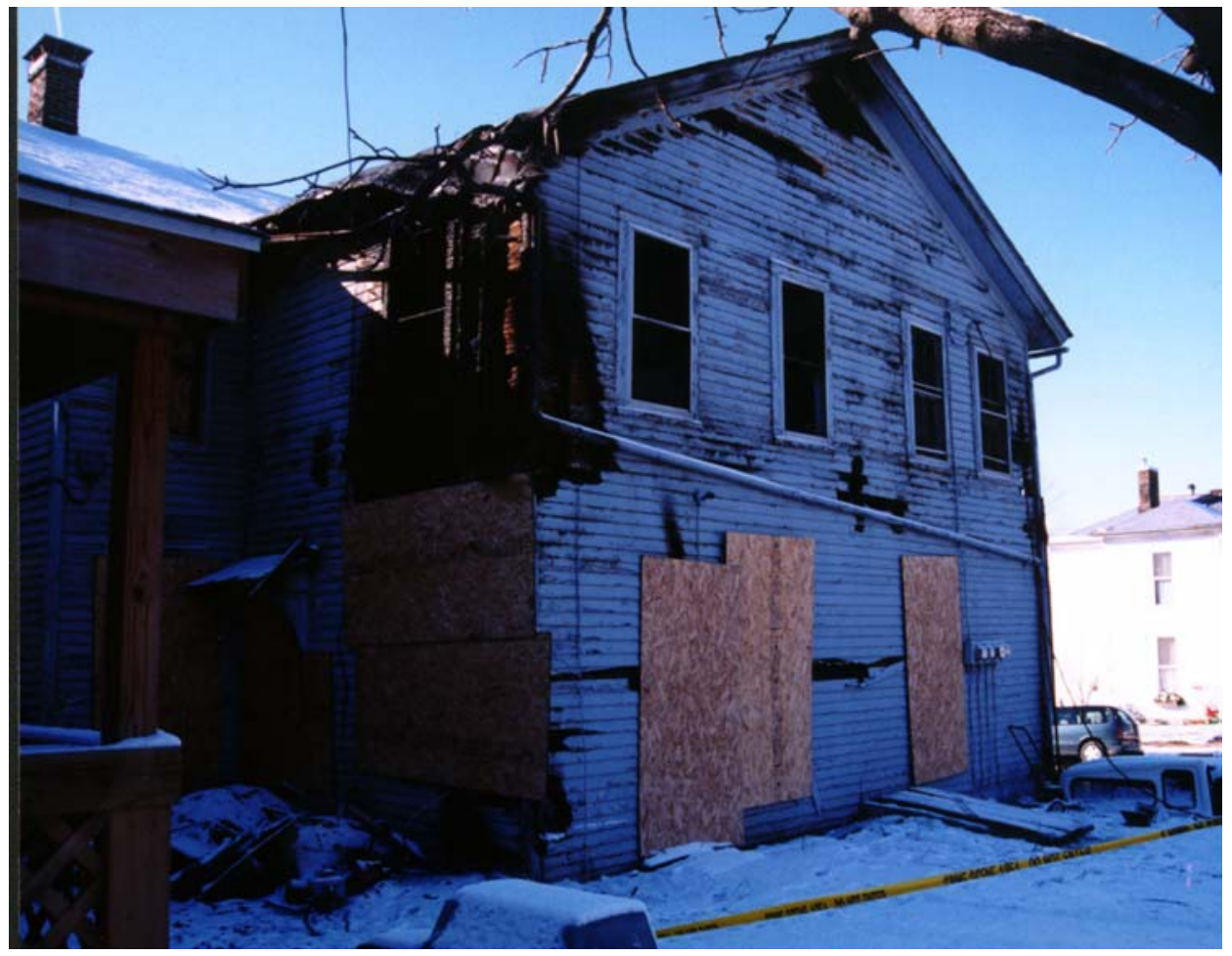

Figure 2. Back of structure. 


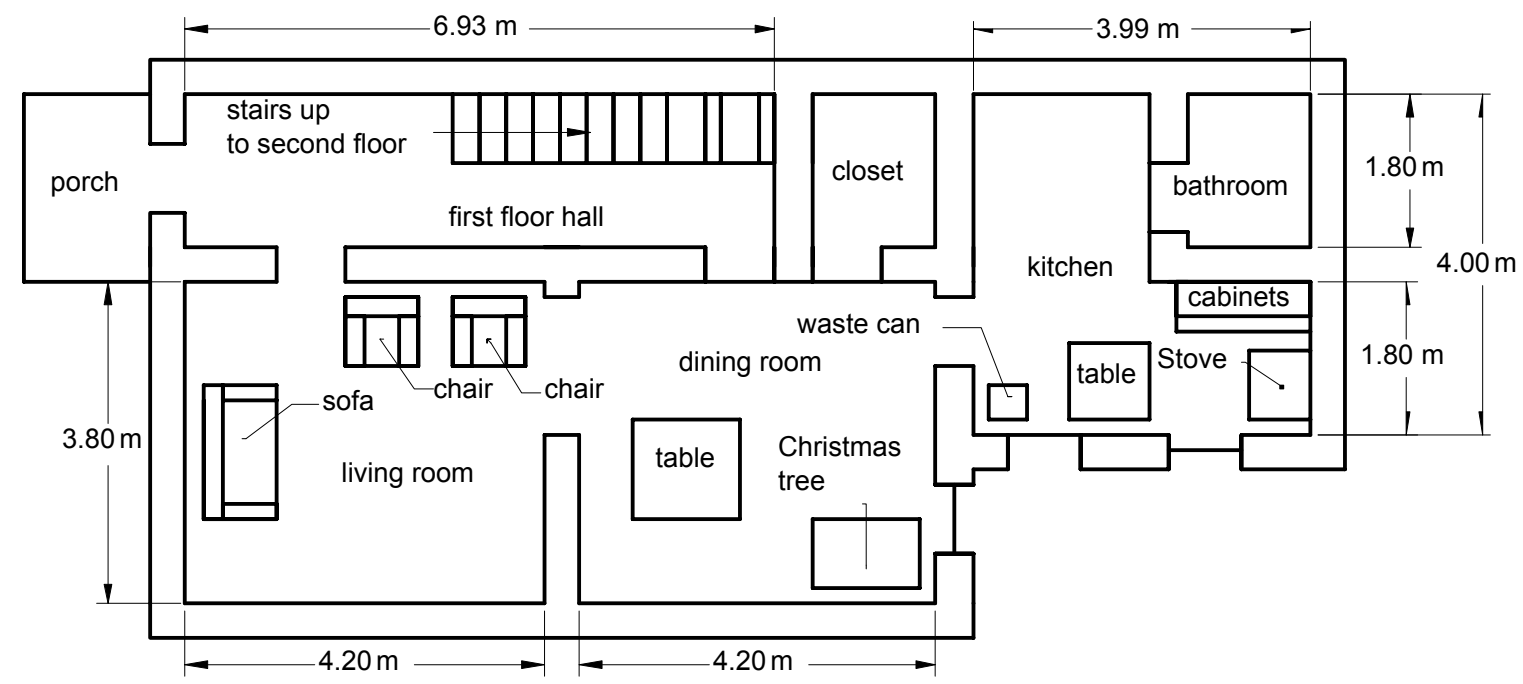

Figure 3. Plan view of $1^{\text {st }}$ Floor. Ceiling height of $1^{\text {st }}$ floor $2.8 \mathrm{~m}$, except for kitchen area, $2.4 \mathrm{~m}$. 


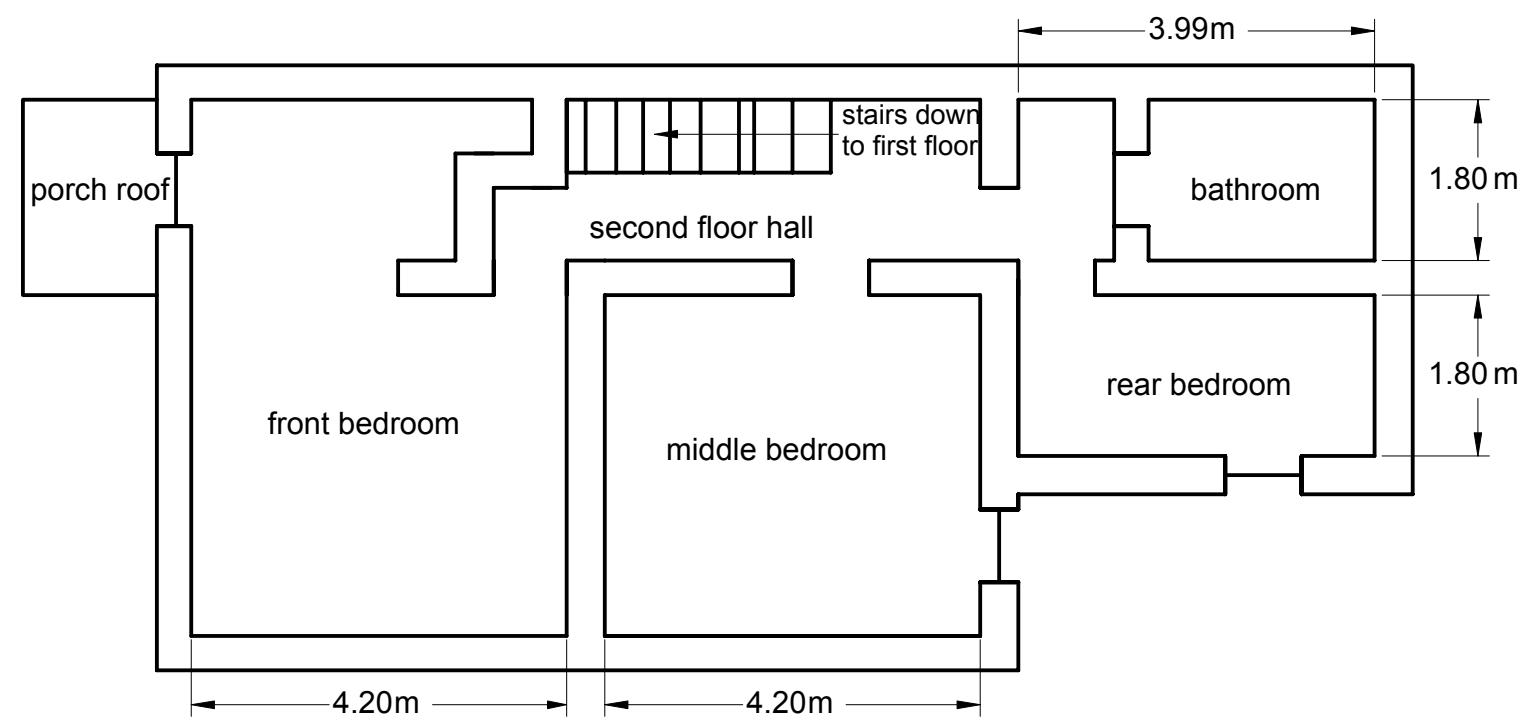

Figure 4. Plan view of $2^{\text {nd }}$ Floor. Ceiling height $2.4 \mathrm{~m}$. 


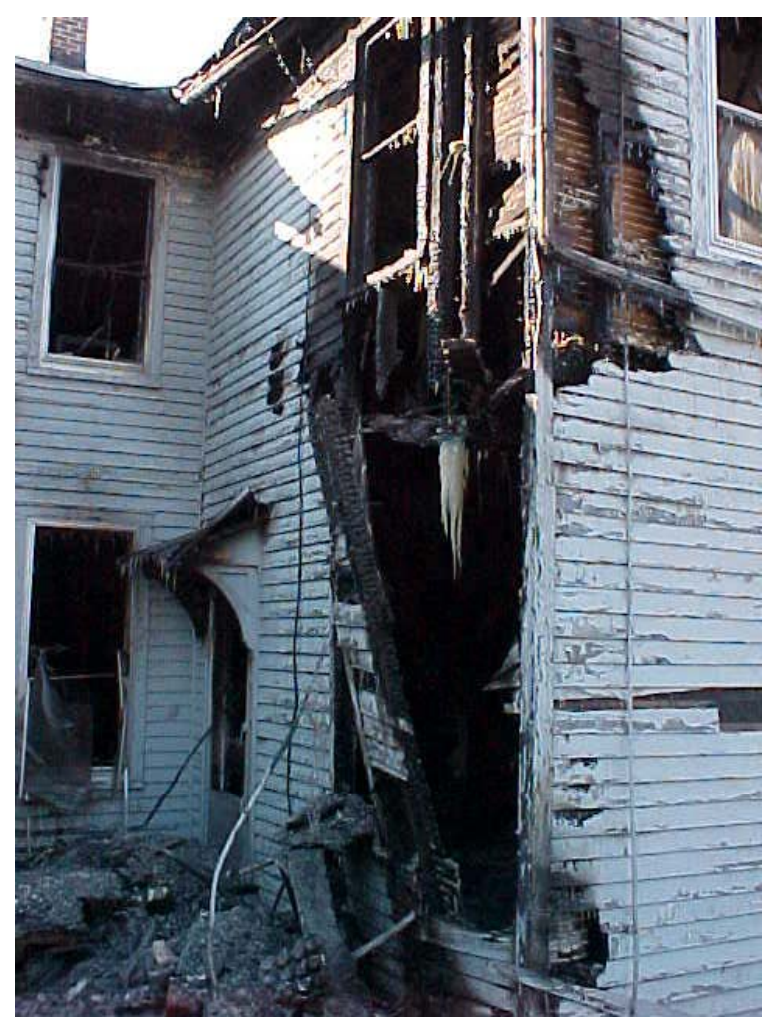

Figure 5. Results of fire extension from kitchen window up to rear bedroom.

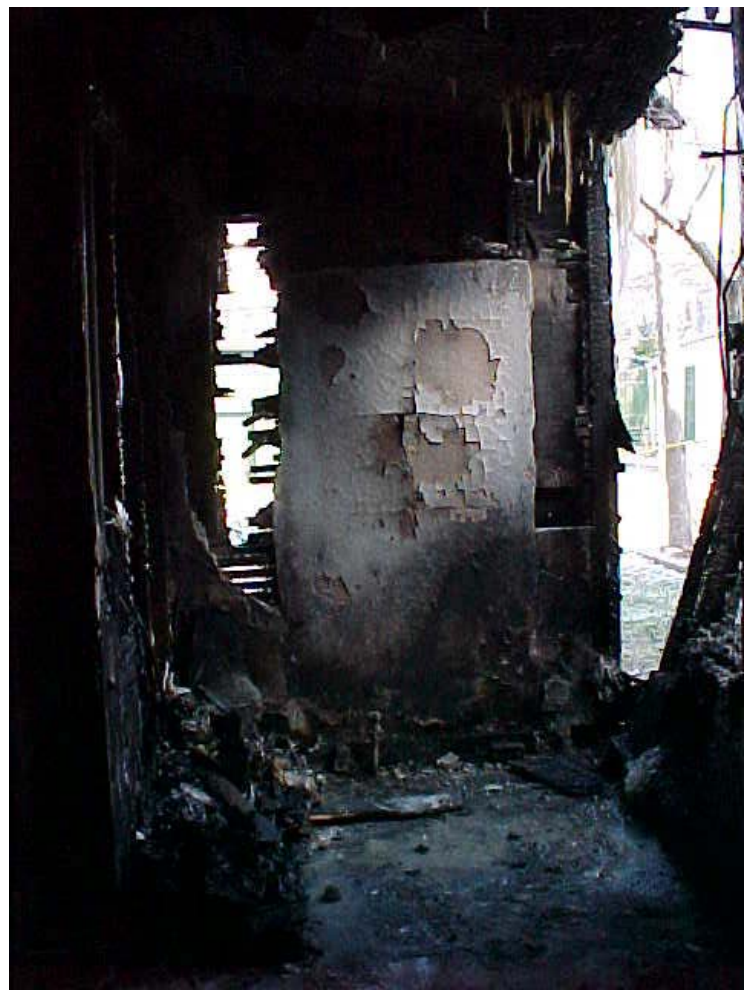

Figure 6. Inside view of kitchen, area of origin. 


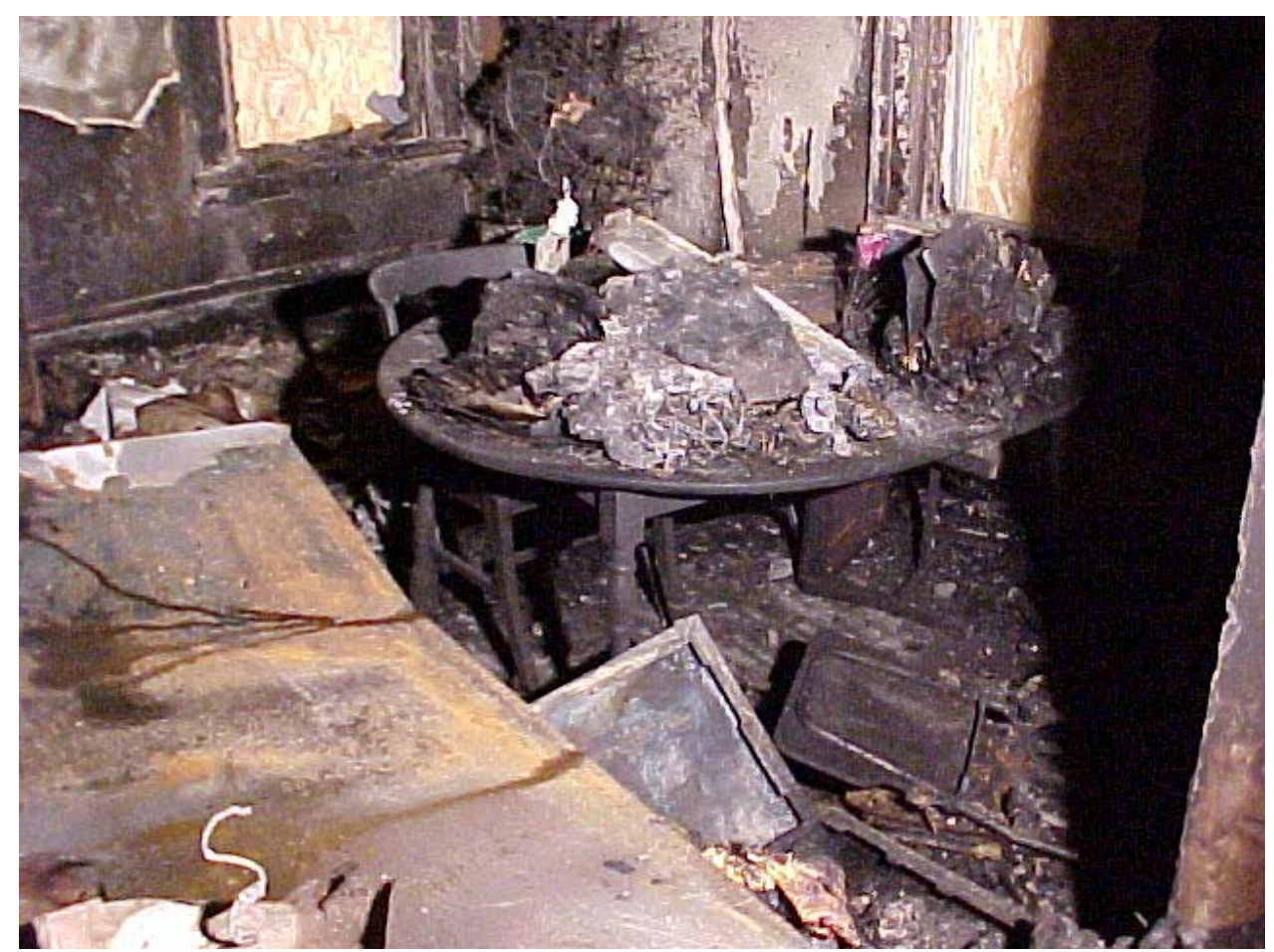

Figure 7. Dining Room with table and chairs.

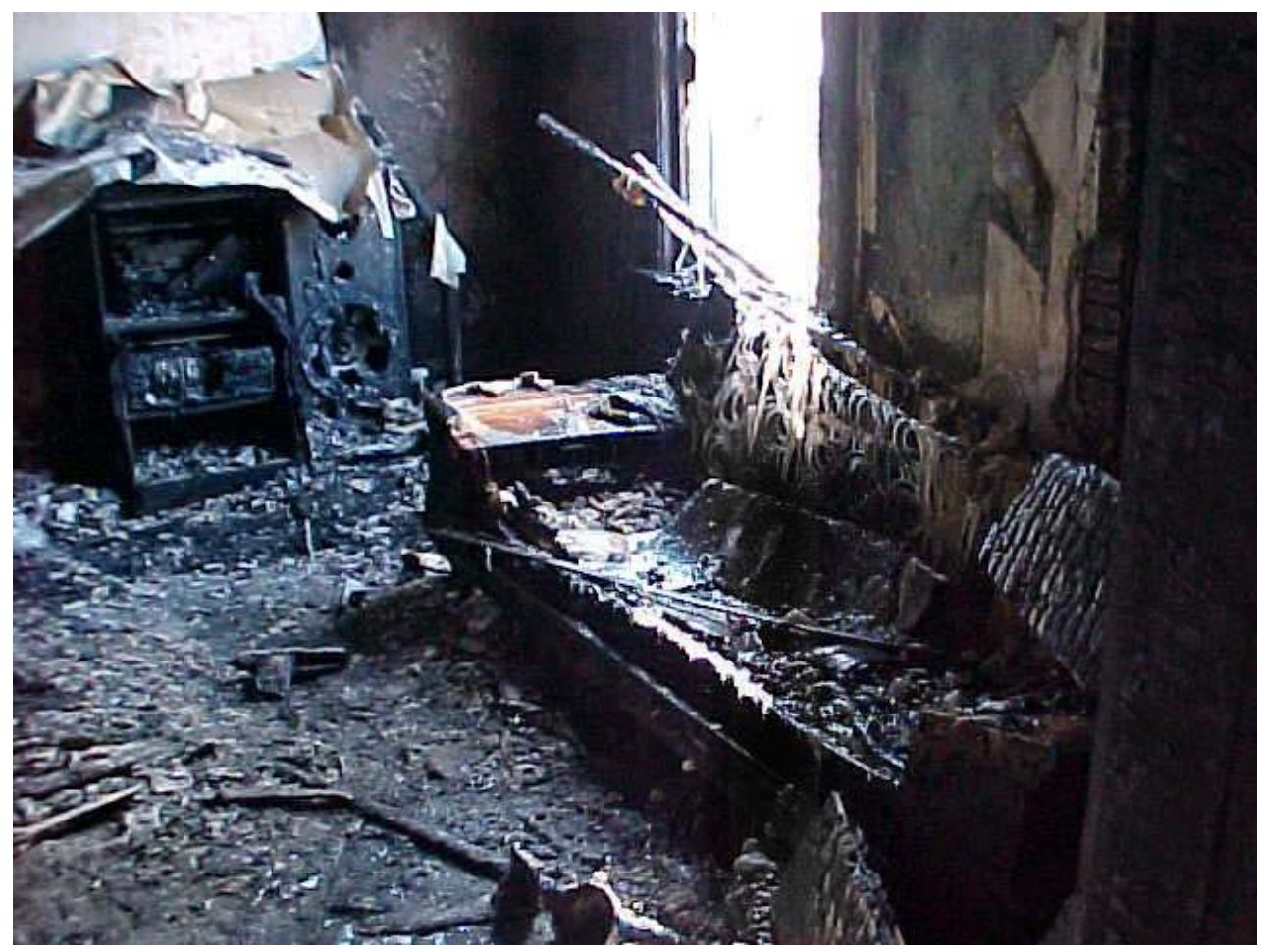

Figure 8. Living room with sofa from front hall doorway. 


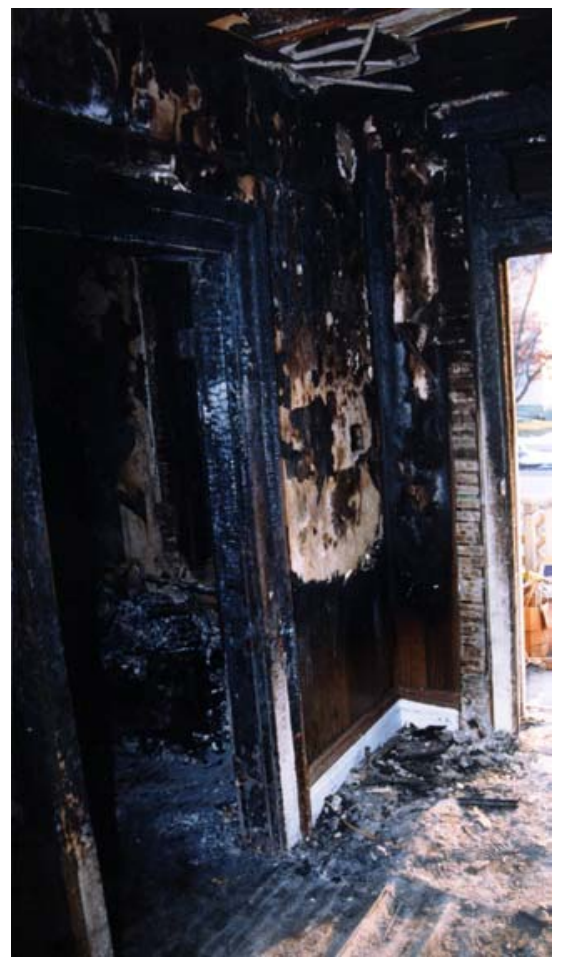

Figure 9. $1^{\text {st }}$ floor hall with doorway to living room on left $\&$ front doorway on right.

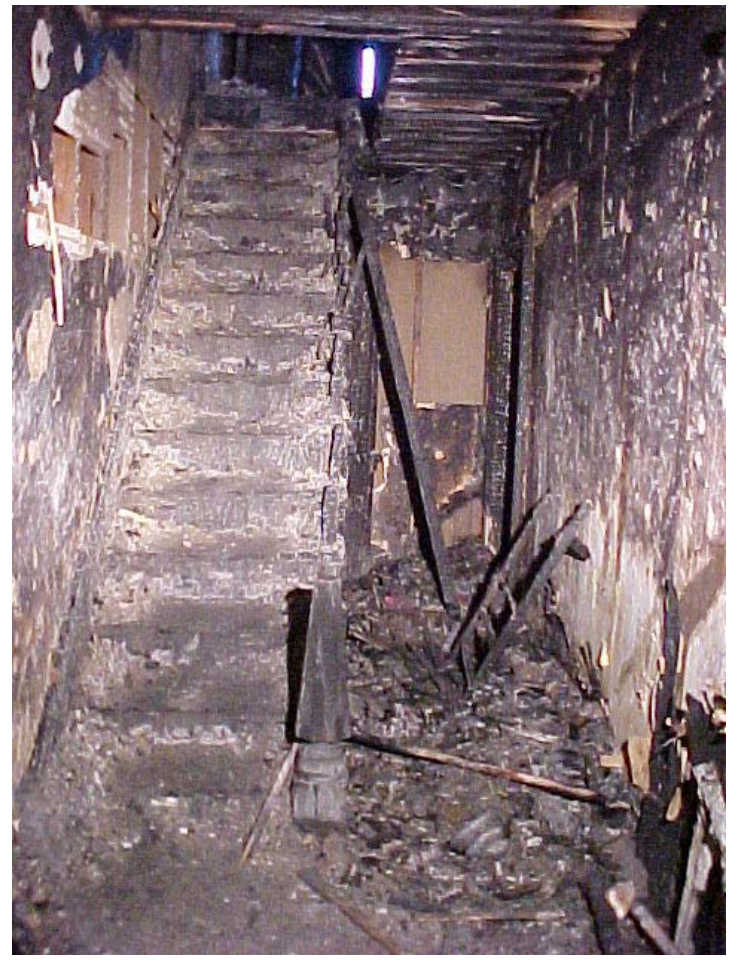

Figure 10. Stairway and $1^{\text {st }}$ floor hall from front doorway. 


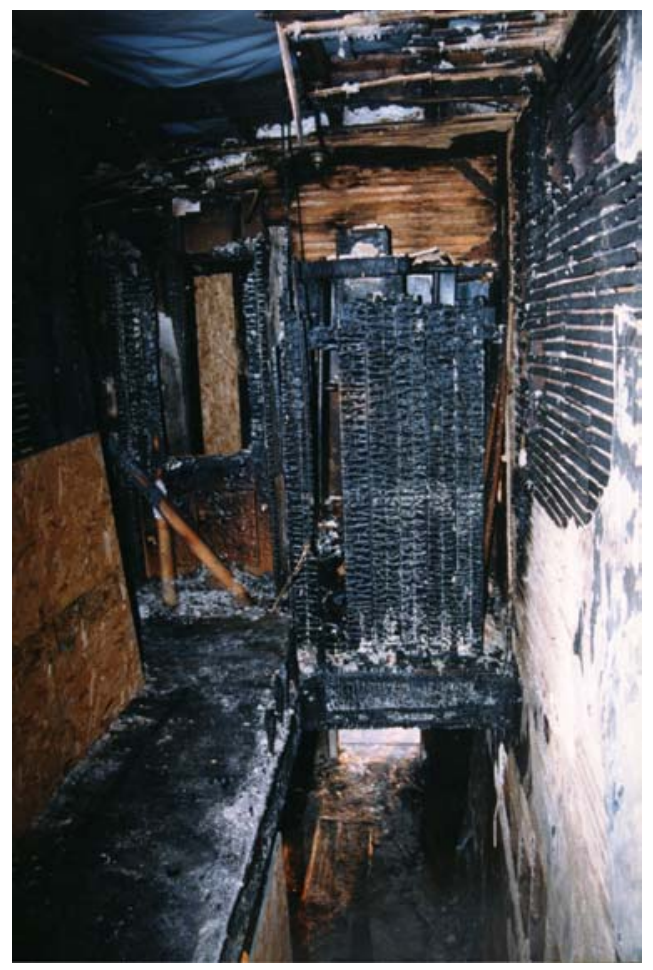

Figure 11. Second floor landing and stairwell looking toward front of structure.

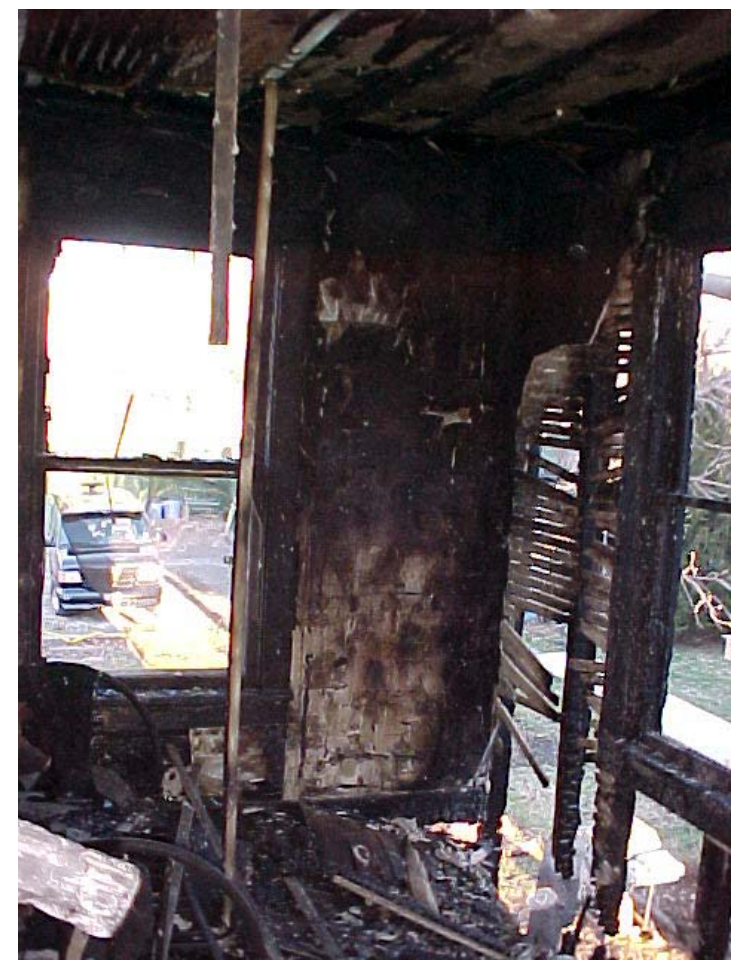

Figure 12. Rear bedroom above kitchen. 


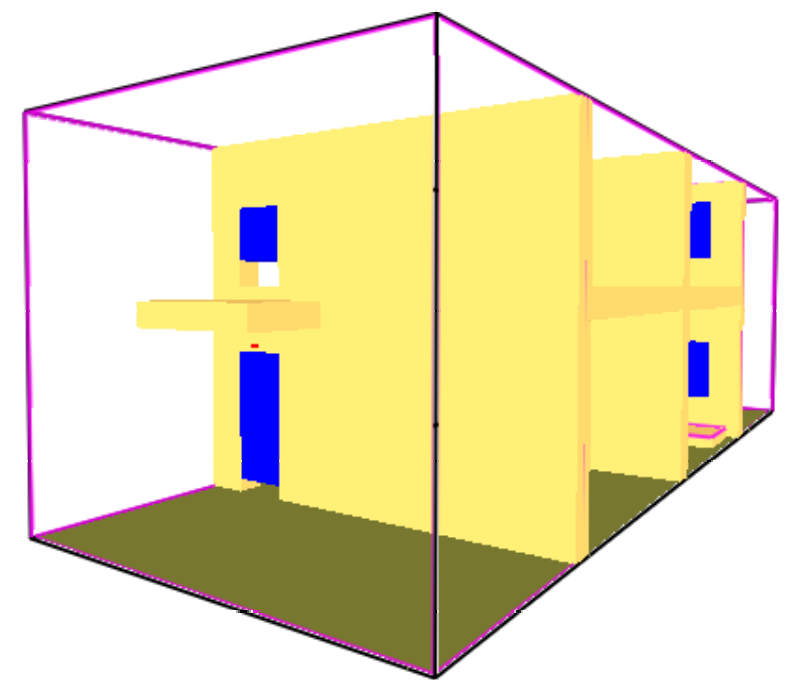

Figure 13. Right front of duplex. Front bedroom window shown with lower portion open. Front door shown closed. The outer box frame represents the boundary of volume modeled.

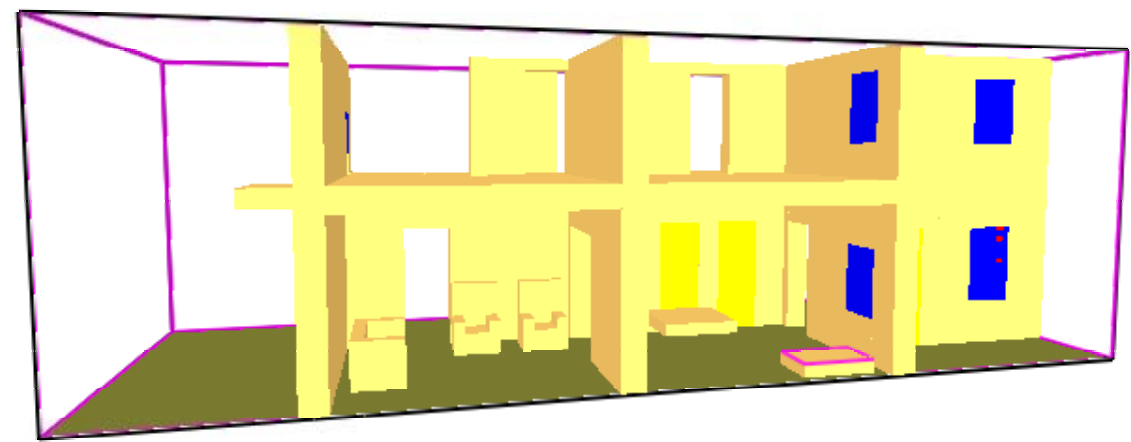

Figure 14. Yard side of duplex. Outer wall removed to show living room and dining room on the first floor and front and middle bedrooms on the second floor. 


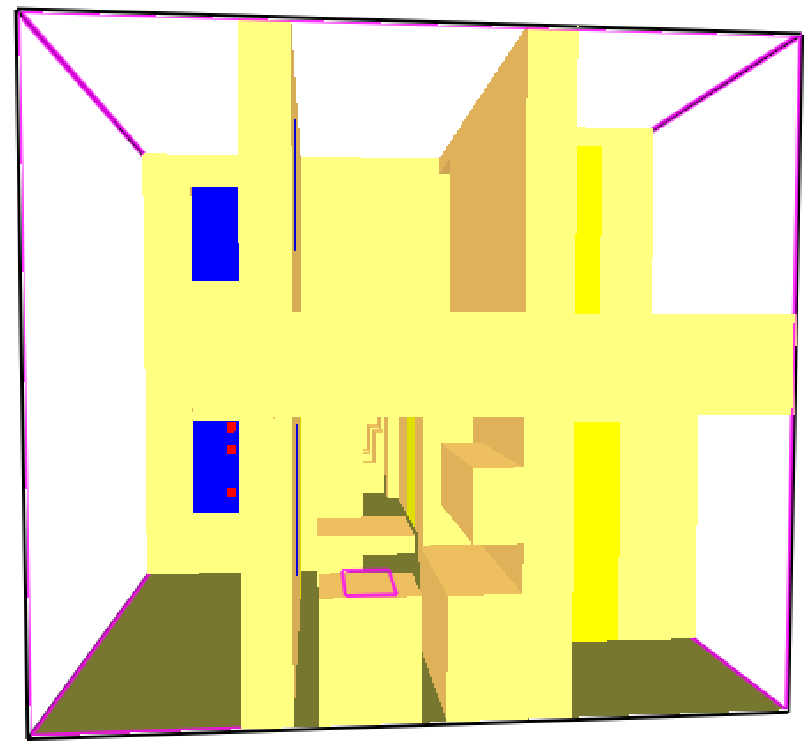

Figure 15. Rear of duplex. The kitchen, with stove and cabinets, and a bathroom are shown on the $1^{\text {st }}$ floor, the rear bedroom, above the kitchen, and a bathroom are on the $2^{\text {nd }}$ floor.

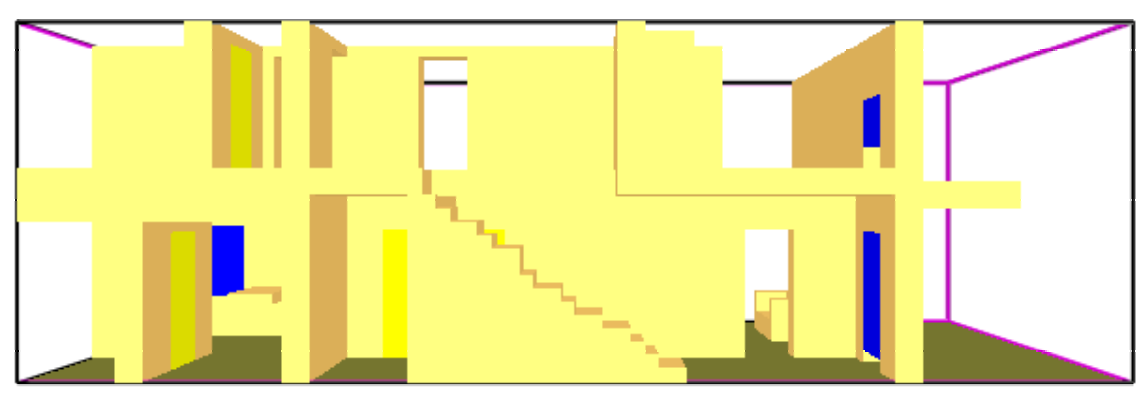

Figure 16. Shared side of duplex. The rear of the duplex is on the left of the figure. From the left, a bathroom, the kitchen, a closet under the stairs, the stairway and lower hall can be seen on the $1^{\text {st }}$ floor. Also from the left, a bathroom, upper hall and front bedroom can be seen on the $2^{\text {nd }}$ floor. 


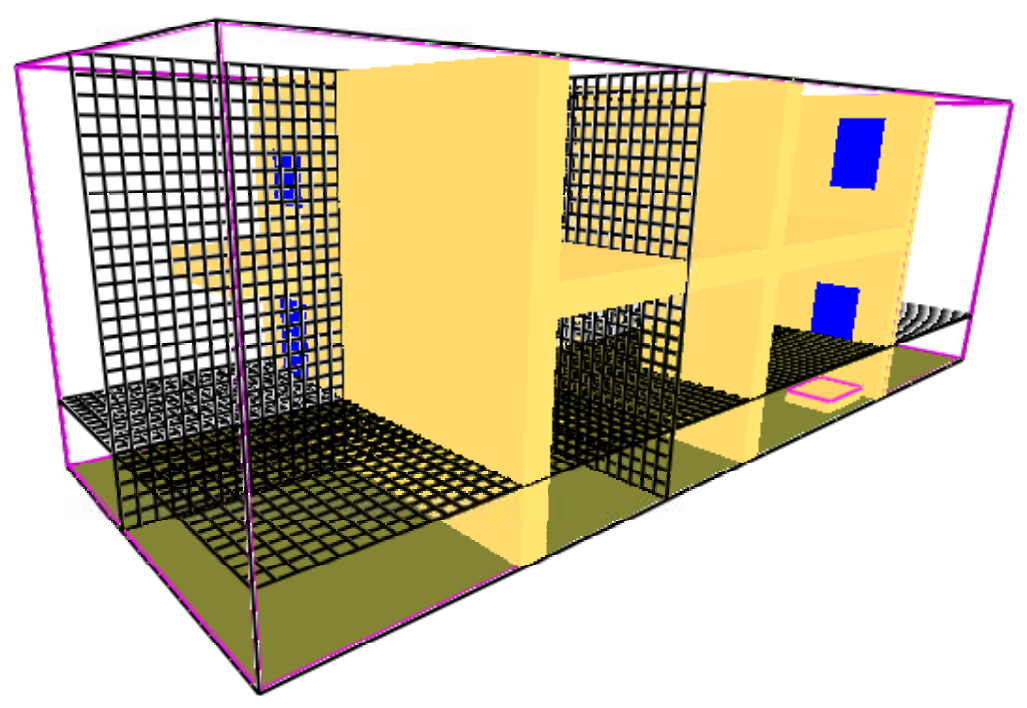

Figure 17. Example of 3 dimensional grid arrangement.

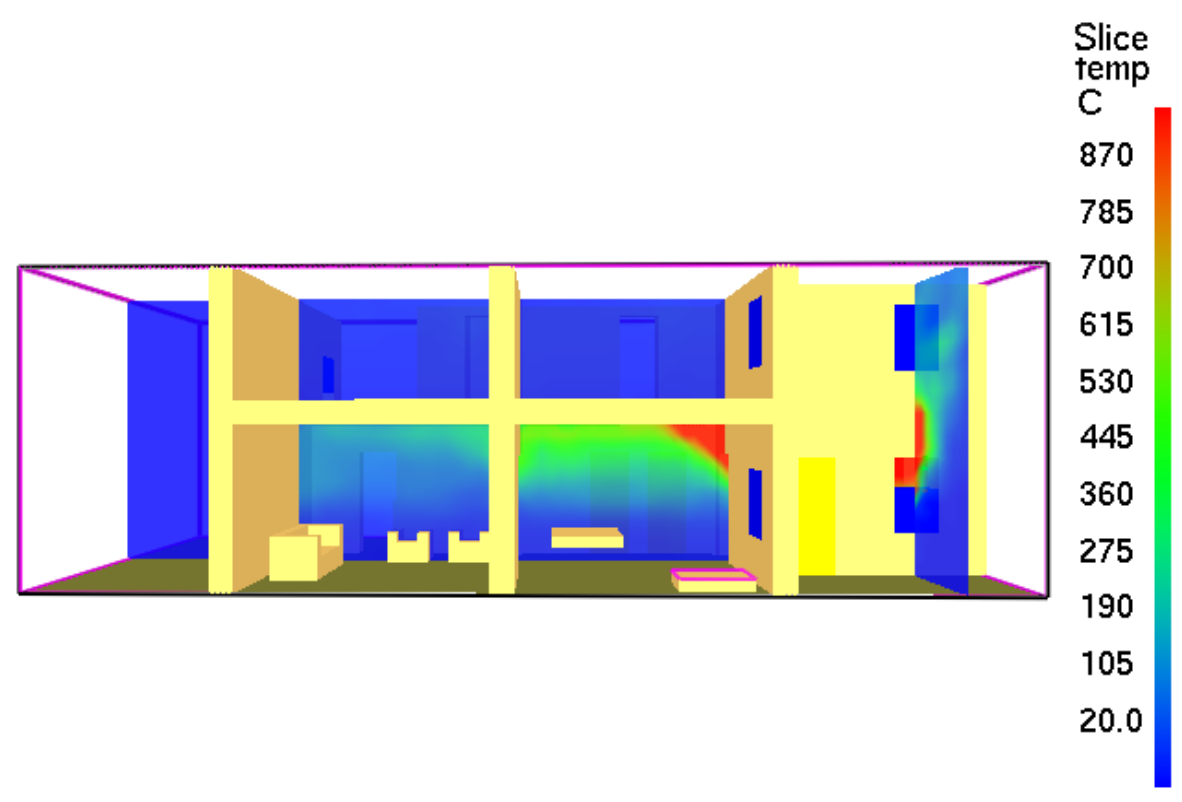

Time: 491.0

Figure 18. Thermal conditions at approximately 8:32 AM (491 s into simulation). 


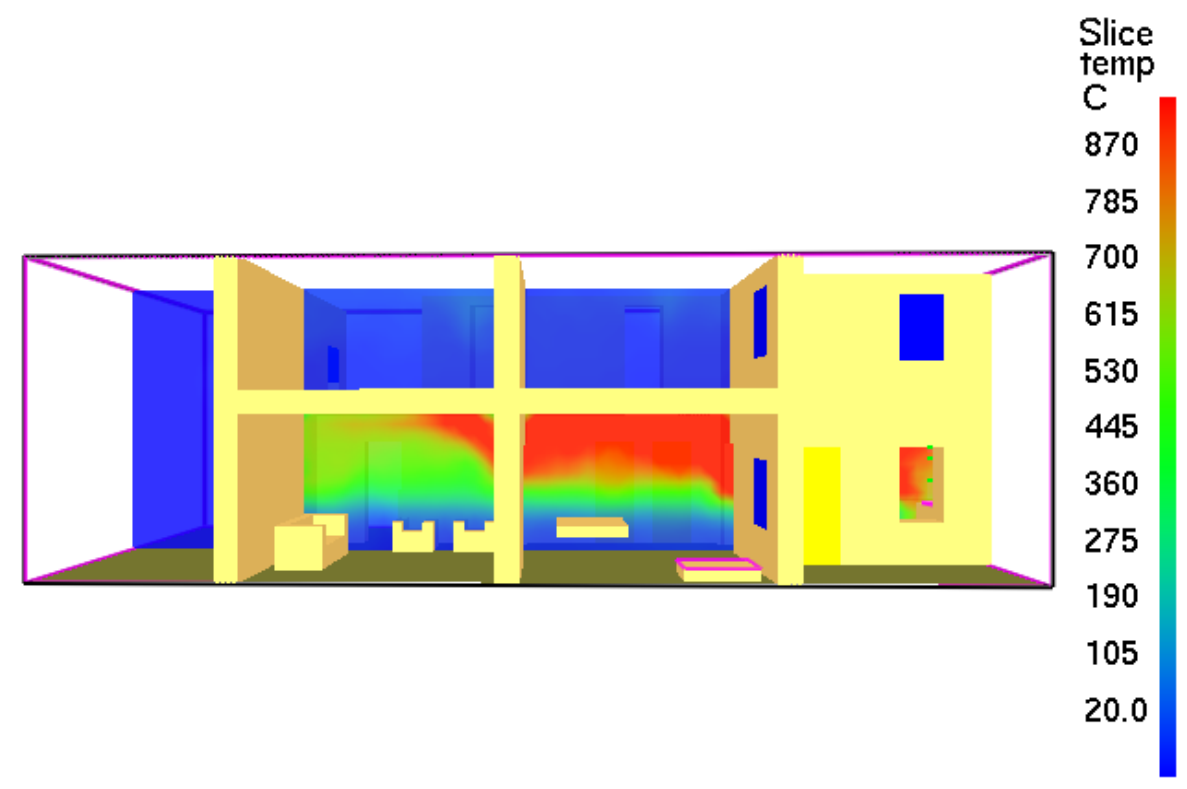

Time: $\mathbf{5 2 4 . 0}$

Figure 19. Thermal conditions at approximately 8:33 AM (524 s into simulation).

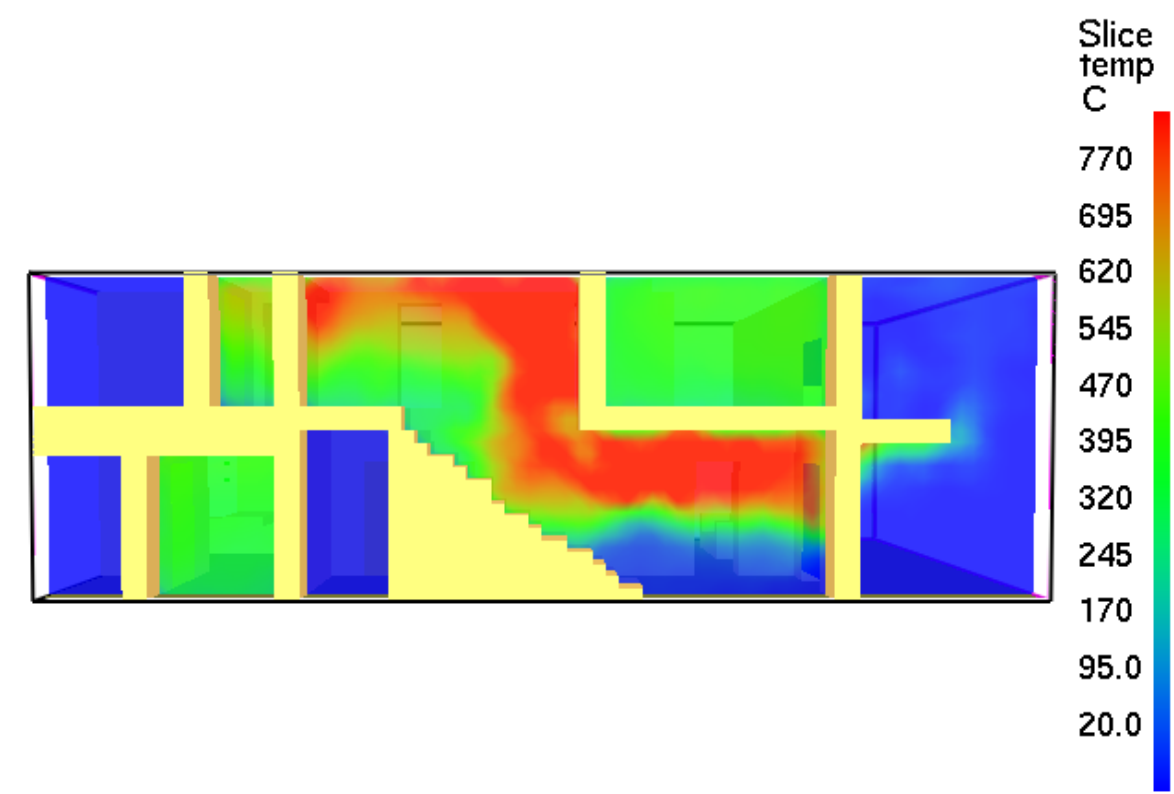

Time: 605.0

Figure 20. Thermal conditions at approximately 8:34 AM (605 s into simulation). 


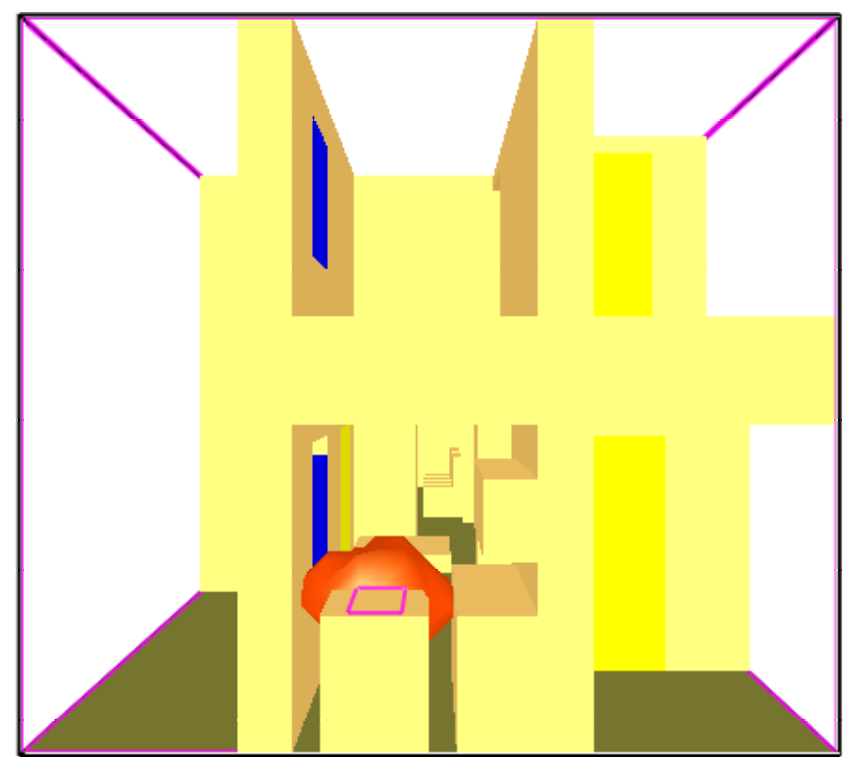

Time: 224.0

Figure 21. Estimated flame boundary covering stove top at approximately 8:28 AM.

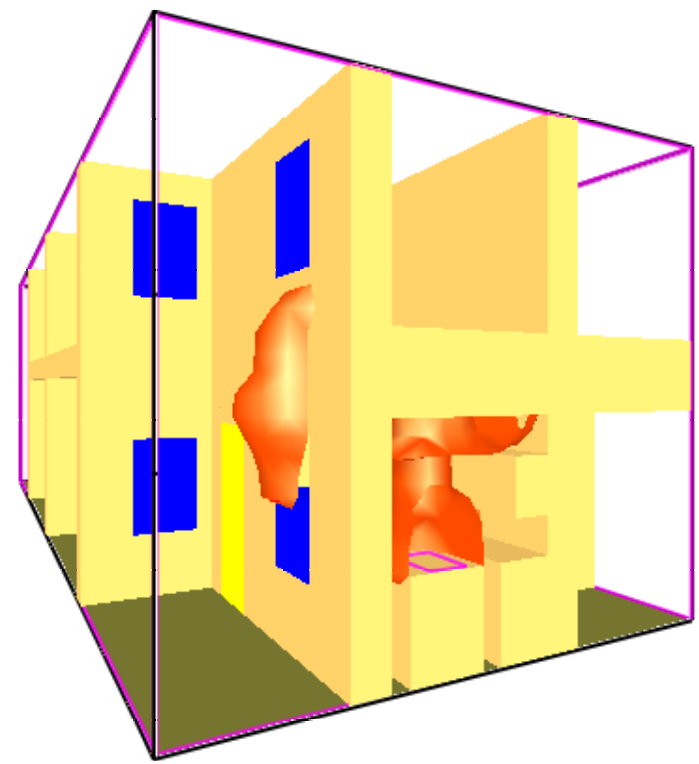

Time: 491.0

Figure 22. Estimated flame boundary extending across kitchen ceiling and venting out of upper portion of kitchen window at approximately 8:32 AM. 


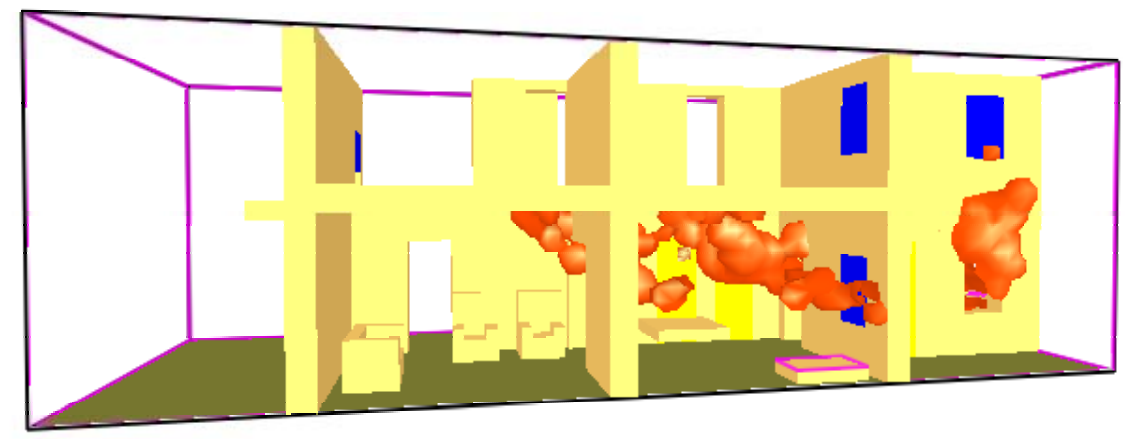

Time: $\mathbf{5 2 4 . 0}$

Figure 23. Estimated flame boundary spreading through the dining room and into the living room at approximately 8:33 AM. Flames continue to spread up the outside of the kitchen.

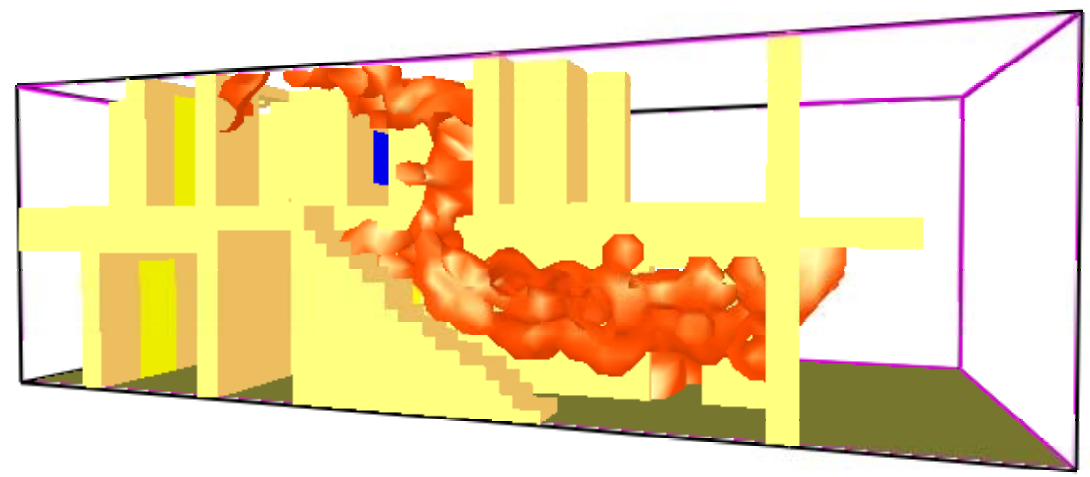

Time: 605.0

Figure 24. Estimated flame boundary spreading through the dining room and into the living room at approximately 8:34 AM. 